\title{
Have budget funds allocated for mitigating corona crisis been spent in an open and accountable manner?
}

Franić, Josip; Bronić, Mihaela

Source / Izvornik: IPF Notes, 2021, 14, 1 - 6

Journal article, Published version

Rad u časopisu, Objavljena verzija rada (izdavačev PDF)

https://doi.org/10.3326/in.2021.118

Permanent link / Trajna poveznica: https:/urn.nsk.hr/urn:nbn:hr:242:314287

Rights / Prava: Attribution-NonCommercial-NoDerivatives 4.0 International/ImenovanjeNekomercijalno-Bez prerada 4.0 međunarodna

Download date / Datum preuzimanja: 2023-04-26

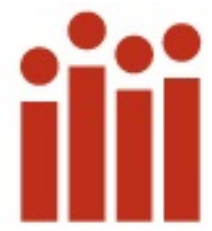

Institute of Public Finance Repository

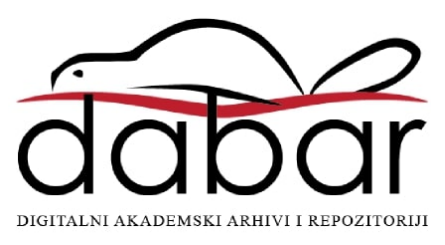




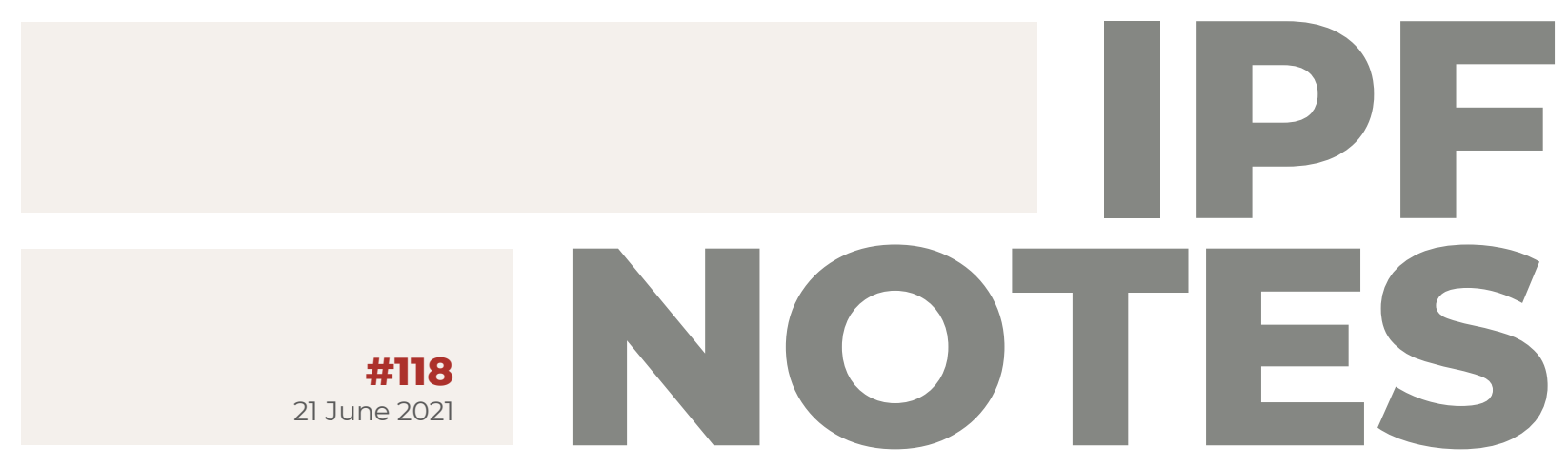

\section{Have budget funds allocated for mitigating corona crisis been spent in an open and accountable manner?}

Josip Franić, Mihaela Bronić

Institute of Public Finance, Zagreb

International Budget Partnership published the results of its research on openness and accountability when spending central government budgetary funds for alleviating COVID-19 crisis. The research covered the period between 7 March and 30 September 2020 and analysed 720 countries, including Croatia, whose fiscal measures that had been implemented for the purpose of mitigating healthcare and economic consequences of the crisis partially satisfied international standards of timely provision of information and consultation with interested stakeholders. The Government and the Parliament should, therefore, ensure that crisis measures are adopted and implemented in a more open and higher-quality manner. For instance, all details of public procurement contracts should, whenever possible, be published in machine readable form on relevant websites. In addition, members of the public should be allowed to take part in designing, adopting and implementing crisis measures. 
The International Monetary Fund estimated that the amount of fiscal interventions into healthcare and economic systems caused by the COVID-19 crisis (hereinafter: "crisis measures") reached USD 14 trillion by end-2020 alone. Although justified, these interventions are also accompanied by significant risks regarding unreasonable and non-transparent spending of public funds. In order to establish the extent to which the processes of adopting, executing and monitoring crisis measures have been aligned with international standards of budget openness, the International Budget Partnership, a Washington-based nonprofit organization, analysed in detail around 400 emergency fiscal policy packages adopted in the period between 1 March and 30 September 2020 in 120 countries all over the world.?

The research was based on the assessment of 26 indicators divided into three groups with the ultimate aim of providing answers to the following questions:

1) to what extent were central governments transparent when adopting and implementing crisis measures;

2) to what extent were national parliaments and audit offices involved in the process and

3) whether the general public was able to adequately participate in the process. ${ }^{2}$

\footnotetext{
1 The research focused exclusively on funds provided in the central government budget, which includes direct financial support, tax reliefs and all fiscal measures related to loans and other forms of liquidity support. Measures implemented by central banks as well as by regional and local government units were not included in the present research.

2 More detail about the methodology is provided here.
} 
Table 1. Openness of central government budgets for mitigating corona crisis ${ }^{3}$

\begin{tabular}{|c|c|c|}
\hline $\begin{array}{l}\text { Level of } \\
\text { openness }\end{array}$ & $\begin{array}{c}\text { Number of } \\
\text { countries in } \\
\text { category }\end{array}$ & Countries \\
\hline Substantive & 0 & - \\
\hline Adequate & 4 & Australia, Norway, Peru, Philippines \\
\hline Some & 29 & $\begin{array}{l}\text { Bangladesh, Brazil, Bulgaria, Canada, } \\
\text { Chile, Colombia, Costa Rica, Croatia, Fiji, } \\
\text { France, Germany, Indonesia, Italy, } \\
\text { Jamaica, Japan, Kyrgyz Republic, } \\
\text { Mongolia, New Zealand, Nigeria, } \\
\text { Paraguay, Poland, Portugal, Sierra Leone, } \\
\text { Slovakia, Slovenia, South Africa, Sweden, } \\
\text { United Kingdom, United States }\end{array}$ \\
\hline Limited & 55 & $\begin{array}{l}\text { Afghanistan, Angola, Argentina, Armenia, } \\
\text { Azerbaijan, Bolivia, Bosnia and } \\
\text { Herzegovina, Botswana, Cameroon, } \\
\text { China, Côte d'Ivoire, Czech Republic, } \\
\text { Dominican Republic, Ecuador, El } \\
\text { Salvador, Georgia, Ghana, Guatemala, } \\
\text { Honduras, Jordan, Kazakhstan, Kenya, } \\
\text { Lesotho, Liberia, Madagascar, Malaysia, } \\
\text { Mali, Mexico, Moldova, Mozambique, } \\
\text { Namibia, Nepal, Nicaragua, Niger, North } \\
\text { Macedonia, Pakistan, Papua New } \\
\text { Guinea, Romania, Russia, Rwanda, } \\
\text { Senegal, Serbia, Somalia, South Korea, } \\
\text { Spain, Sri Lanka, São Tomé e Príncipe, } \\
\text { Thailand, Timor-Leste, Togo, Trinidad and } \\
\text { Tobago, Uganda, Ukraine, Vietnam, } \\
\text { Zambia }\end{array}$ \\
\hline Minimal & 32 & $\begin{array}{l}\text { Albania, Algeria, Benin, Burkina Faso, } \\
\text { Burundi, Cambodia, Chad, Comoros, } \\
\text { Dem. Rep. of Congo, Egypt, Equatorial } \\
\text { Guinea, Eswatini, Ethiopia, Hungary, } \\
\text { India, Iraq, Lebanon, Malawi, Morocco, } \\
\text { Myanmar, Qatar, Saudi Arabia, South } \\
\text { Sudan, Sudan, Tajikistan, Tanzania, The } \\
\text { Gambia, Tunisia, Turkey, Venezuela, } \\
\text { Yemen, Zimbabwe }\end{array}$ \\
\hline
\end{tabular}

3 The final results, derived by calculating the share of positive answers in the set of questions related to each of the three segments of budget openness defined above, are provided in descriptive form for easier understanding. Additional information is provided in the methodology document. 
Even though the sudden shock and urgent need for financial intervention made it unrealistic to expect that considerable levels of openness would be attained, the results presented in Table 1 show that only Australia, Norway, Peru and the Philippines provided their citizens with adequate budgetary information and ensured an adequate role for all stakeholders. Croatia, together with the majority of the analysed EU countries, has been categorised into the group of countries that partially met international standards of budget openness when adopting and executing crisis measures. On the other hand, almost threefourths of countries demonstrated limited or minimal openness levels.

Croatia records such an outcome primarily due to adequate amounts of information provided regarding the introduction and implementation of the crisis measures adopted by the Government during March and April 2020 (Table 2). This partially compensates for poorer results recorded for the role of institutions competent for oversight of the adoption and implementation of crisis measures and minimal participation of interested public in the adoption and implementation processes. 
Table 2. Openness of central government budget for mitigating corona crisis in Croatia

\begin{tabular}{|cl}
\hline $\begin{array}{l}\text { Area of budget openness } \\
\text { TRANSPARENCY }\end{array}$ & Information availability level \\
$\begin{array}{l}\text { Introduction of the package (crisis } \\
\text { measures) }\end{array}$ & Adequate \\
Macroeconomic and aggregate & Substantive \\
\hline Policy measures & Substantive \\
\hline Recipients and performance & Some \\
\hline Sources of funding & Some \\
\hline $\begin{array}{l}\text { Extra-budgetary funds } \\
\text { measures) }\end{array}$ & Minimal \\
\hline Reporting on execution & Adequate \\
\hline Extra-budgetary funds & Adequate \\
\hline Public procurement & Substantive \\
\hline Area of budget openness & Limited \\
\hline OVERSIGHT & Role of analysed stakeholders \\
\hline Role of Parliament & LIMITED \\
\hline Role of State Audit Office & Some \\
\hline PARTICIPATION & Minimal \\
\hline Public participation & MINIMAL \\
\hline
\end{tabular}

Note: Minimal openness 0-0.2 points; limited openness 0.21-0.4 points; some openness 0.41-0.6 points; adequate openness 0.61-0.8 points; substantive openness 0.81-1.0 points

Source: IBP (2021)

In order to ensure more open and higher-quality adoption and implementation of crisis measures in the future - since the quality of measures largely depends on the awareness and inclusion of all stakeholders in their adoption process - the Government and Parliament might be assisted by the following examples of good practice highlighted in the research: 
- USA created the website "Pandemic Oversight", which provides a thorough overview of the 19 crisis programmes, including expenditure data.

- Ecuador's Public Procurement Agency enables open access to information on all public procurement contracts at the page "Urgent public procurement".

- The State Audit Service of Sierra Leone published its report on the audit of funds used for mitigating the crisis, which was used by the Anti-corruption Agency to conduct several investigations which even led to some arrests.

- In Norway, the executive and legislative authorities conducted relevant consultations with key stakeholders during the formulation and implementation of crisis packages.

In addition, the Croatian Government and Parliament could enhance openness and accountability when adopting and implementing crisis measures in the following manner: (1) by publishing monthly data on the implementation of each individual measure; (2) by publishing on their websites all relevant details about public procurement contracts in machine readable form, whenever possible; (3) by encouraging the State Audit Office to conduct audits related to crisis measures in as short periods of time as possible; (4) by enabling appropriate modes of public participation in the formulation, adoption and implementation of crisis measures. 